Article

\title{
The EU's Recovery and Resilience Facility: A Next Phase in EU Socioeconomic Governance?
}

\author{
Sonja Bekker ${ }^{1,2}$ \\ ${ }^{1}$ Research Cluster on Empirical Legal Studies into Institutions for Conflict Resolution-ERI, Utrecht University, \\ The Netherlands; E-Mail: s.bekker@uu.nl \\ 2 Department of Private, Business \& Labour Law-PBLL, Tilburg University, The Netherlands
}

Submitted: 21 March 2021 | Accepted: 1 June 2021 | Published: 13 August 2021

\begin{abstract}
The European Semester (Semester) was implemented a decade ago. Ample research has addressed the Semester's development, including some major changes in processes and content (Verdun \& Zeitlin, 2018). The Covid-19 crisis seems to mark the next stage in the evolution of the Semester. It connects the Semester with the wider Recovery and Resilience Facility (RRF) and links its country-specific recommendations to conditional financial support. Thus, the next stage of the Semester suggests a stronger and more deliberate interlinkage of different EU tools that jointly guide national socioeconomic policies. It should support both national public investment and reforms while focusing on meeting the EU priority of moving towards a climate-neutral, digitalized, and resilient Europe (De la Porte \& Dagnis Jensen, 2021). This article addresses the question of what room the new-style Semester gives to the involvement of national-level actors, such as national parliaments. Therefore, it expands existing analytical frameworks in order to assess the RRF in connection to the Semester, focusing on the degree of obligation, enforcement, and centralisation. Jointly, this outlines the room the RRF gives to the participation of national actors in the Semester. The article concludes that although the national parliaments are not mentioned in the Regulation establishing the RRF, they could claim a role both in developing national plans for accessing financial support as well as in amending and approving reforms.
\end{abstract}

\section{Keywords}

European Semester; European social policy; national parliament; Recovery and Resilience Facility

\section{Issue}

This article is part of the issue "Rising to a Challenge? Ten Years of Parliamentary Accountability of the European Semester" edited by Eric Miklin (University of Salzburg, Austria), Aleksandra Maatsch (University of Wroclaw, Poland) and Tomasz P. Woźniakowski (Hertie School, Germany).

(C) 2021 by the author; licensee Cogitatio (Lisbon, Portugal). This article is licensed under a Creative Commons Attribution 4.0 International License (CC BY).

\section{Introduction}

This article deals with the next stage in the evolution of the European Semester (Semester) which is marked by its interlinkage with the Resilience and Recovery Facility (RRF). Tying the Semester to a new EU instrument, among others, adds conditional financial support as a new way to drive national reforms. This article assesses the room the Regulation establishing the RRF (EU, 2021) leaves for national actors, in order to influence the design and implementation of reforms, including reforms as suggested by the Semester's coordination practices. The article is structured in six parts. In the next section, it summarises the developments in the first decade of the Semester's existence, emphasising its ability to adapt to new and country-specific goals as well as its (growing) practice of including actors across governance levels in the different stages of policymaking. Section 3 turns to the current development of tying the Semester to the RRF, focusing in particular on the quite novel instrument of using financial conditionality as a way to drive national reforms. Section 4 gives theoretical starting points for the assessment of this new phase of the Semester, while Section 5 analyses the Regulation establishing the RRF (in terms of the room for stakeholder involvement) assessing the degree of 
obligation, enforcement, and centralisation. Section 6 presents the conclusions.

\section{The First Decade of the Semester}

The Semester may be labelled as quite an innovative governance model that evolves or adapts to new socioeconomic challenges and governance ideas (Verdun \& Zeitlin, 2018). Its inception in 2011 was a firm reaction to the challenges posed by the large financial and economic crisis of 2008-2013. Stricter rules on maximum debt and deficits should improve national compliance with EU rules, while suggestions for structural reforms should improve the economic and financial position of member states. Accordingly, the EU reinforced the Stability and Growth Pact (SGP) and introduced the Macro-Economic Imbalances Procedure (MIP). The Semester unites the MIP and the SGP, and adds social and employment coordination. It thus creates a single time frame for coordination activities in the wider socioeconomic domain (Bekker \& Klosse, 2013). Accordingly, the Semester hosts several coordination mechanisms, each consisting of different methods to drive or force member state reform, including semi-binding and nonbinding rules, political discussions, the exchange of ideas, scoreboards with quantitative indicators, and qualitative analyses. The result is that the degree of direct impact of the Semester on member states depends on the policy topic at hand, the country concerned, the assumed urgency for reform, and the input of national and EU-level stakeholders (Bekker, 2021). One of the outcomes of the Semester is a list of country-specific recommendations (CSRs) which gives reform suggestions to member states. These CSRs may stem from the SGP, MIP, or the softer employment and social policy coordination.

During the first decade of its existence, the Semester sparked quite fierce debates on legitimacy, national autonomy, effectiveness, and the domination of economic over social goals (Chang et al., 2019; Copeland \& Daly, 2015; Crum \& Merlo, 2020; De la Porte \& Heins, 2015; Vanheuverzwijn \& Crespy, 2018; Verdun \& Zeitlin, 2018; Woźniakowski et al., 2021). Moreover, quite a number of countries, those in dire need of financial support, were taken out of the Semester coordination activities and placed in even stricter programmes. For instance, Greece, Portugal, Ireland, Latvia, Hungary, Romania, Cyprus, and Spain entered into bailout programs that entailed loans upon reform conditions, laid down in a Memorandum of Understanding (Jacoby \& Hopkin, 2020). The detrimental effects of these reforms on both fundamental social rights and democratic standards have been heavily criticized (Kilpatrick \& de Witte, 2014). However, non-programme countries, that remained in the Semester coordination cycle, such as Italy, also received "important EU instructions with a social focus" which put additional pressure on them to reform (Kilpatrick \& de Witte, 2014, p. 2), or faced similar pressure to reform given their dire financial situation (e.g., Slovenia; see Munta, 2021). It raised questions, for instance by the Parliamentary Assembly of the Council of Europe (2012), that called for a reorientation of austerity programmes in order to prevent the undermining of democratic standards (Kilpatrick \& de Witte, 2014).

Over time, the Semester adapted to the increasing call for a more social Europe, while policymakers learned how to engage in the Semester processes (Zeitlin \& Vanhercke, 2018). After 2015, important changes were made to the Semester, including extending the coordination cycle to a full year. In the first semester of each year, the European Commission proposes, and the Council endorses, targets and guidelines. Next, in the second Semester, policy guidance should be translated into national policies and legislation (Papadopoulos \& Piattoni, 2018). These changes in the Semester aimed to give national governments more time to involve national parliaments, social partners, and other stakeholders in discussing policy measures vis-à-vis national budgets and accordingly improve national ownership (Alcidi \& Gros, 2017; Vanheuverzwijn \& Crespy, 2018). Jointly, the Semester's characteristics of being adaptable, using a combination of several hard and soft legal instruments, and including actor involvement across governance levels, make the Semester hard to define when using simple binary distinctions. Its operation lingers somewhere between the economic and the social, the supranational and the intergovernmental, and the technocratic and democratic poles of EU governance (Verdun \& Zeitlin, 2018). Thus, the Semester may be an excellent example of multilevel governance, involving the dynamic interaction of EU-level and national-level actors (Cardwell \& Gaglia Bareli, 2020). National government representatives, trade unions and employers' associations, and parliaments may all play a role at the different stages of the coordination process, influencing norm-setting, policy design, implementation, and evaluation. Although the role of actors is growing, their role could be strengthened considerably, including the role of national parliaments (Crum, 2018; Eurofound, 2016; Munta, 2021; Sabato et al., 2017). Also, a sense of national ownership of the Semester seems somewhat lacking among national stakeholders, particularly national parliaments, although there is variation across countries (Vanheuverzwijn \& Crespy, 2018). Yet, proper stakeholder involvement could facilitate the striking of a balance between social and economic goals, as well as between the national and international views and democratic and technocratic forces. The next section addresses what seems to be the next stage of the Semester, as European efforts to recover from the Covid-19 pandemic have had an impact on the Semester.

\section{The Next Stage of the Semester}

The impact of the Covid-19 pandemic might mark the next stage in the Semester's evolution because the Semester plays a role in the newly installed RRF. 
The Regulation establishing the RRF (12 February 2021) gives member states access to grants and loans. The RRF is part of the Next Generation EU (NGEU), the EU's fiscal and policy response to the Covid-19 pandemic, aiming to rebuild a Europe that is greener, more digital, and more resilient. The NGEU is completely new and set out to be a temporary recovery instrument encompassing $€ 750$ billion (De la Porte \& Dagnis Jensen, 2021). Within the NGEU, the RRF offers $€ 672.5$ billion in loans ( $€ 360$ billion) and grants ( $€ 312.5$ billion) to member states to support their reforms and investments. The tone with which these new instruments are introduced seems quite 'investment' and 'human' friendly, thus contrasting with the former 'austerity' recipe during the financial crisis (Antonucci \& Corti, 2020). Additionally, it breaks with former EU ideas to avoid common debt issuance and will create redistribution across member states through grants (De la Porte \& Dagnis Jensen, 2021). Glancing at reactions in some of the member states, there seems to be a great deal of political attention given (e.g., Poland, Italy), although this does depend on the country and its political situation (e.g., little discussion in the Netherlands; compare Dutch Government, 2021; Fleming et al., 2021; Kość \& Tamma, 2021). Moreover, at times countries seem to struggle with preparing streamlined plans that meet the detailed expectations of the $\mathrm{EU}$, for instance on stakeholder involvement and ensuring transparency in the process (Jakubowska et al., 2021).

The RRF and the Semester are 'intrinsically linked' (European Commission, 2021a). In 2021, the deadlines of the two mechanisms will overlap. Moreover, the Semester is adjusted temporarily, releasing some of the reporting pressure on countries. Furthermore, financial support is conditional on reform as recommended by the CSRs. Generally, CSRs encompass many different socioeconomic policy areas, and may focus on recovery from the crisis, but also try to address longer-term goals such as the EU's Green Deal, a digital transition, and establishing inclusive societies. In 2021, no structural CSRs will be given to member states that have submitted national recovery and resilience plans (NRRPs). Instead, older CSRs play a role, meaning that member states' reform plans need to meet the reform suggestions given in 2019 and 2020.

Despite these changes being presented as temporary, the aspect of conditionality is worth exploring, as it builds on experiments with conditionality in the past. Moreover, tying the Semester to the RRF opens up discussions on solidarity among member states. It creates the need to have parliaments involved when deciding on financial support related to the expectance of certain (socioeconomic) reforms. Normally, financial solidarity between member states would require enhanced input of national parliaments, as redistributive aspects necessitate collective will-formation, ensuring that decisions may be justified to those who will have to deal with the negative consequences of redistribution (Crum \& Merlo, 2020). However, previous examples of national parliaments being bypassed and pressured into massive reforms as a condition for loans, as happened in the bailout countries during the financial and economic crisis, raised criticism concerning the impact on fundamental social rights and democratic standards (Kilpatrick \& de Witte, 2014). Moreover, the idea that national reforms can be bought is quite problematic, certainly given the national competencies and demands of the electorate (Alcidi \& Gros, 2017).

Moreover, a range of difficulties exists when steering top-down in complex and politically sensitive issues. For instance, reform effects in the socioeconomic domain are hard to predict, as well as the cause-andeffect of reforms (or a lack of reforms). Some reforms require long-term planning in dialogue with relevant stakeholders, making expectations of quick implementation unrealistic and even undesired (Bekker, 2017; Wieser, 2020). Given this complexity, the measurement of the implementation of CSRs is likewise difficult, not the least because CSRs often collate different priorities and policy areas (Alcidi \& Gros, 2017; Wieser, 2020). This questions the harsh verdicts given on the low effectiveness of the Semester in terms of quick and complete implementation of the reforms suggested by the CSRs. While CSRs have not always been at the centre of attention of national policymakers (Wieser, 2020), the purpose of the Semester is to engage in joint exploration and recursive learning among member states and the European Commission, on multi-dimensional objectives, allowing for provisional solutions to uncertain problems in diverse national contexts (cf. Zeitlin, 2016). In the latter case, fast and simple compliance with CSRs might not only be unrealistic but also is not the main purpose of the coordination process. Rather, creating conditions for member states to set course to meet longer-term goals would be the purpose, such as meeting the three 2030 headline targets agreed on at the Porto Social Summit (May 2021): Having at least 78\% of people aged 20 to 64 in employment, at least $60 \%$ of all adults participate in training every year, and lowering the number of people at risk of poverty or social exclusion by at least 15 million, including at least 5 million children. Indeed, the setup of the Semester purposely includes that effects are mediated by the national decision-making procedures (Crum, 2020). This allows national actors to suggest alternative policy solutions to the Commission (Bekker, 2021). The question thus is, what the impact is of tying the Semester to the RRF, particularly on the role of national actors. Would it make the Semester more of a supranational structure, or would it keep valuing the Semester as a process that lingers somewhere in-between intergovernmental and supranational (Verdun \& Zeitlin, 2018)?

Costamagna and Goldmann (2020) fear that the availability of a large sum of money enhances the Commission's capacity to exercise national policy formulation, supervision, and guidance on issues that belong to the core of national economic and social policies. Expectations that the European Commission would not 
wait for member states to submit their NRRPs, but rather play an active part already in their formulation (Costamagna \& Goldmann, 2020), seem to have come true. The European Commission (2021b) says that the NRRPs have been handed in after an 'intensive dialogue' between the European Commission and national authorities. Spanish trade unions have complained about the interference of the European Commission in national social dialogue on plans for the RRF (European Trade Union Confederation, 2021a). Thus, if the link between the Semester and the RRF means prescribing reforms and predicting reform effects, this would require active attention to, and the influence of national stakeholders. This article sheds light on the room that the Regulation establishing the RRF offers to national stakeholders. Therefore, it first expands existing analytical frameworks to assess the Semester 'new style,' looking at the degree of obligation, enforcement, and centralisation. Before analysing the Regulation establishing the RRF, the next section first gives an analytical framework in order to structure the assessment.

\section{Theory: Involvement of National-Level Actors in New EU Governance}

Changes in EU governance during the Covid-19 crisis make it important to determine what changed, for instance in terms of policies and who governed in what ways (Schmidt, 2020). Do the changes add up to a paradigmatic shift toward deeper European integration? Are these changes incremental, is there a reversal toward dis-integration, or does it depend on the policy area at hand (Schmidt, 2020)? Generally, new EU governance models, such as the Semester, might be difficult to capture using a single theory on EU integration (Hooghe \& Marks, 2019; Scharpf, 2002; Schmidt, 2018; Verdun \& Zeitlin, 2018). A combination of different theories might be more appropriate to understand and explain all the different mechanisms that operate in a multilevel setting where actors interact, and where different hard and soft law norms are combined. Scharpf (2002) uses insights from four theoretical strands for an assessment of modes of multilevel interaction. The first is 'mutual adjustment,' where national governments are makers of their own national-level policies. They do not do this in isolation but may respond to the policies of other governments or countries. This mode leaves ample space for national actors, such as parliaments, to influence decision-making. A second mode of multilevel interaction is 'intergovernmental negotiation,' which institutionalises interaction to some degree, albeit in a limited way. Here, national governments agree to coordinate or standardise national policies at the EU level. However, they remain in full control of their decision-making process, which thus includes a role for national parliaments. In the third and fourth modes of multilevel interaction are 'joint decision' and 'hierarchical direction' where the role of the EU level is larger (Scharpf, 2002). Joint decision combines elements of intergovernmental negotiation and supranational centralisation. Hierarchical direction centralises competencies completely to the EU-level and supranational actors, excluding national governments from participation. Schmidt (2018) includes the role of the parliament more directly in her depiction of new EU governance. Departing from grand theories on EU integration (intergovernmentalism, supranationalism, and parliamentarism), Schmidt (2018) calls for a widening of the scope of analysis beyond a focus on which actor exercises which kind of power. Rather, empirical analyses should establish which kind of power or combination of powers are relevant in a given case, capturing elements of politicization and dynamic interaction among both intergovernmental and EU level actors (Schmidt, 2018). This includes general political interests, for instance on how national electoral politics affect EU level decisionmaking (Schmidt, 2018). This article builds on such ideas by using an analytical framework that is nuanced enough to distinguish degrees of more centralised and less centralised multilevel interaction, even within one coordination mechanism. This is especially useful when exploring the Semester, which never becomes totally supranational or totally national (Verdun \& Zeitlin, 2018). At the same time, depending on the topic, the country, and the year of scrutiny, the Semester may shift to becoming 'harder' or 'softer' in its coordination (Bekker, 2021).

Building on degrees of 'hard' and 'soft' law coordination, while encompassing the new element of conditional financial support (see also De la Porte \& Heins, 2015), it seems worthwhile to explore the degree of bindingness of CSRs. Developing the work of Abbott et al. (2000), Saurugger and Terpan (2021, p. 1) judge the nature and content of acts and norms by placing them on a continuum. Accordingly, they define soft law as "based on a continuum running from non-legal positions to legally binding and judicially controlled commitments with, in between these two opposite types of norms, commitments that can be described as soft law." Two criteria, obligation and enforcement, further establish the degree of softness of a norm. These criteria may be complemented by the degree of centralisation, particularly when exploring the Semester (Bekker, 2021; De la Porte \& Heins, 2015; see Table 1). The degree of obligation arises from the nature of the act (on a scale from hard obligation to no obligation) and the content of the norm (the degree of clarity and/or density of a norm). The degree of enforcement depends on whether acts or norms within acts are submitted either to judicial control or to a very constraining form of non-judicial control and allows one to take into account a range of mechanisms that ensure that actors fulfil obligations or achieve the assigned goals. It thus includes delegation to a third party, as well as different procedures and instruments such as guidelines, standards, and instructions (Saurugger \& Terpan, 2021). Conditional financial support could be part of the assessment of the degree of enforcement, which was in the case of the programme 
countries in the financial and economic crisis judged as very high (De la Porte \& Heins, 2015). The degree of centralisation depends on whether proposed policy changes are uncontroversial (e.g., minor vs. major policy changes), and the degree of involvement or influence of national actors in drafting or implementing CSRs (Bekker, 2021). De la Porte and Heins (2015, p. 7) address this when assessing the type of objective of EU policy suggestions, letting these range from a low to a very high degree of EU involvement. Moreover, they note that EU policy objectives differ according to welfare state type and policy area. Exactly these kinds of tailored policy suggestions in CSRs, their variation from year to year, as well as the national input in the drafting stage of CSRs, make it debatable that this feature should be placed under the heading of centralisation (see Bekker, 2021). After all, if a CSR were effectively drafted by a member state, and shaped according to its national plans, that CSR would reflect their national policy agenda rather than the European Commission's demands. In case of low centralisation, national governments, parliaments, and social partners may influence suggested reforms, both in the phase of articulating which reforms to prioritise in CSRs, and how these reforms should be designed and implemented. More centralisation would mean less national level influence, e.g., moving toward joint decision or hierarchical direction models. Likewise, CSRs may come across as less centrally driven if they refer to minor policy changes in uncontroversial areas. An example of the opposite: a large reform, would be past CSRs calling for the decentralisation of national systems of wageformation (De la Porte \& Heins, 2015).

The next section further explores conditional financial support as a tool and its consequences for the degree of pressure stemming from the Semester's CSRs.

\subsection{Analysing Conditional Financial Support}

Historically, conditionality has hardly been used in the setting of the EU (Jacoby \& Hopkin, 2020). Rather, international organizations such as the International Monetary Fund, have used it when giving loans to countries. In that context, conditionality may be defined as the provision of financial assistance alongside requirements that the debtor meet specific conditions on macroeconomic policy; thus providing benefits in exchange for implementing specific policies along the lines spelt out by an international organisation (Fink \& Scholl, 2016, p. 176; Jacoby \& Hopkin, 2020). Conditionality should help countries to overcome the problems that caused their dire financial situation as well as ensure that loans are repaid. This conditionality could limit the role of national governments and parliaments to design economic policies as they see fit.

Within the EU, conditionality has become more prominent since the accession of ten new member

Table 1. Analytical framework for hardening and softening trends in a Semester linked to the RRF.

\begin{tabular}{|c|c|c|c|}
\hline Element & & Indicators towards softening & Indicators towards hardening \\
\hline \multirow[t]{2}{*}{ Obligation } & Codification & $\begin{array}{l}\text { Attaching norm to a } \\
\text { non-binding rule: } \\
\text { employment OMC }\end{array}$ & $\begin{array}{l}\text { Attaching norm to a binding } \\
\text { rule: Moving towards MIP } \\
\text { and/or SGP }\end{array}$ \\
\hline & Precision & $\begin{array}{l}\text { Getting less precise: } \\
\text { - Vague description; } \\
\text { - General standards }\end{array}$ & $\begin{array}{l}\text { Getting more precise: } \\
\text { - Unambiguous rules explaining conduct they } \\
\text { require, authorise, or proscribe; } \\
\text { - Highly elaborated or dense, detailing } \\
\text { conditions of application, spelling out } \\
\text { required or proscribed behaviour }\end{array}$ \\
\hline
\end{tabular}

\begin{tabular}{|c|c|c|}
\hline \multirow[t]{3}{*}{ Enforcement } & Moving towards preventive arm & Moving towards corrective arm \\
\hline & Less frequent policy monitoring & More frequent policy monitoring \\
\hline & $\begin{array}{l}\text { Fewer ties with conditional loans } \\
\text { and grants }\end{array}$ & $\begin{array}{l}\text { More ties with conditional loans } \\
\text { and grants }\end{array}$ \\
\hline \multirow[t]{3}{*}{ Centralisation } & $\begin{array}{l}\text { More national actor involvement } \\
\text { in drafting a norm }\end{array}$ & $\begin{array}{l}\text { Less national actor involvement in drafting } \\
\text { a norm }\end{array}$ \\
\hline & Fit with national priorities & No fit with national priorities \\
\hline & $\begin{array}{l}\text { Uncontroversial, not challenging } \\
\text { institutional arrangements, minor } \\
\text { policy changes }\end{array}$ & $\begin{array}{l}\text { Far-reaching structural reforms, undermining } \\
\text { existing institutional set-up, requiring } \\
\text { fundamental change }\end{array}$ \\
\hline
\end{tabular}

Source: Own conceptualisation, following Bekker (2021), who builds on Abbott et al. (2000), De la Porte and Heins (2015), and Saurugger and Terpan (2021). 
states in 2004 and 2007, albeit in quite a specific form: accession conditionality instead of crisis conditionality (Jacoby \& Hopkin, 2020). Since 2008, and directly related to the economic and financial crisis, conditionality has been used more widely to drive national reforms, especially in the case of the bail-out programmes of countries that signed a Memorandum of Understanding with the 'Troika' of the European Central Bank, the International Monetary Fund, and the European Commission (Theodoropoulou, 2015). This conditionality focused on core state functions in the fiscal, labour market, and social policy domains, and some of the demands had already been recommended within 'soft' law coordination prior to the crisis (Jacoby \& Hopkin, 2020). However, bail-out countries were taken out of the Semester coordination activities. Within the Semester, the move from the preventive to the corrective arms of both the SGP and the MIP may mean progressing soft CSRs to stricter demands. Conditionality has also become a more prominent tool in the EU's cohesion funds. Especially after 2014, the EU started adding the requirement to take relevant CSRs into account when designing national programmes, for instance allocating an appropriate amount of funding through the European Social Fund to meeting relevant CSRs (Jacoby \& Hopkin, 2020; Viță, 2018). At present, conditional financial support from the RRF is tied, among others, to the CSRs, finding inspiration in the Memorandum of Understanding used in the former crisis. It came into the RRF following negotiations on the broader NGEU in the European Council as part of a package of concessions. The 'Frugals,' a group of small, rich countries (the Netherlands, Denmark, Sweden, and Austria), were against debt mutualisation and higher EU budgets (De la Porte \& Dagnis Jensen, 2021; Rijksoverheid, 2020). They accepted the RRF as an instrument in the NGEU in exchange for a high level of conditionality for the disbursement of grants and the acceptance by Poland and Hungary of the rule of law as a condition for receiving EU funds (De la Porte \& Dagnis Jensen, 2021).

The next section explores how conditionality, as well as the other aspects relating to obligation, enforcement, and centralisation, has been enshrined in the Regulation that established the RRF, and how it took care to include national actors, in particular the national parliament.

\section{The Regulation Establishing the RRF: Obligation, Enforcement, and Centralisation}

The grants and loans in the RRF are voluntary in nature. However, countries that have been affected more by the crisis, might be in more need of EU funds than those that can finance recovery themselves (Crum, 2020). For each, a maximum of available funding has been calculated. By 17 May 2021, 18 members states handed in an official NRRP (European Commission, 2021a). The Regulation is aware that it introduces a novelty in stimulating national reforms. Its preamble states that as yet, there were no instruments foreseeing direct financial support linked to the achievement of results as well as to the implementation of reforms and public investments of member states, for instance, responding to the Semester. Moreover, the Regulation addresses its interconnection with other programmes and instruments more than once, for instance referring to the EUInvest programme, other sources of funding and the Semester, and aims to foster synergies (Art. 28). Regarding the Semester, member states have to hand in NRRPs, which are annexed to the Semester's national reform programmes. The information in these two reports should be coherent, but there should also be consistency with the National Energy and Climate Plans, the European Green Deal and the Digital Agenda, the just transition plans, the Youth Guarantee Implementation Plan, and the partnership agreements and operational programmes adopted under the EU cohesion funds. On top of that, NRRPs need to be consistent with the Semester's CSRs (Article 17-3 Regulation). For euro area countries, this includes coherence with the most recent euro area Council recommendations. Alignment with the Semester also happens at the monitoring and evaluation stage. This interlinkage of the RRF with other programmes co-determines the reform direction of member states wanting to access grants and loans. The messages in the CSRs are then one of the conditions for receiving financial support, and also feed the evaluation criteria for assessing the use of the grants and loans. How the RRF influences the degree of obligation, enforcement, and centralisation in connection to the Semester, is explored below.

\subsection{Degree of Obligation}

The Regulation speaks of achieving 'milestones' and 'targets' of reforms and investments, which need to be set out in NRRPs, written by member states. Such milestones and targets refer to one aspect of obligation: the degree of precision of promised reforms. This degree of precision is substantial, and, as described above, themes are pretty much pre-defined. Article 17 of the Regulation, on eligibility, mentions that NRRPs shall form a comprehensive and coherent package. Article $18-4$ sets out a long list of details (covering 20 subsections from $\mathrm{a}-\mathrm{t}$ ). For instance, the plan shall be duly reasoned and substantiated, explaining how the plan contributes to the six priority areas (or pillars) that the EU has defined in Art. 3 of the Regulation. These priorities are a green transition; digital transformation; smart, sustainable and inclusive growth; social and territorial cohesion; health, and economic, social and institutional resilience; and policies for the next generation, children and the youth, such as education and skills. A Commission staff working document gives very detailed guidance and structure for writing the NRRPs, including the elements that the reports should cover and its coherence with EU-level objectives. Moreover, the NRRPs should contribute to meeting the country-specific challenges and CSRs (also 
if attached to the excessive imbalance procedure). This aspect may limit the freedom of countries to design their preferred reforms. However, CSRs may be influenced by national actors before they are endorsed by the Council, and moreover leave much room to further flesh out precise reforms at the implementation stage (e.g., Zeitlin \& Vanhercke, 2018). Moreover, the Regulation offers scope for member states to propose alternative reforms.

Additional details are requested on the distribution of grants and loans over the EU's priorities. Here, the EU predetermines that at least $37 \%$ should be allocated to the green transition and at least $20 \%$ to the digital transition. Also, an indicative timetable for implementation, as well as investments to be completed by 31 August 2026 should be part of the NRRPs (Art. 18-4(i)). Additionally, referring to stakeholder inclusion, the plan should summarise the consultation process with which the member state included local and regional authorities, social partners, civil society organisations, youth organisations, and other relevant stakeholders. Interestingly, the plan should be clear about the input of the stakeholders in the NRRPs. Or, as the European Trade Union Confederation (2021b, p. 27) rephrases it, governments should install robust coordination mechanisms, both for the planning and implementation phases, involving social partners. The European Commission staff working document gives more details on how the NRRPs should reflect stakeholder involvement, both in the design and implementation stages. This includes:

The scope (list of consulted social partners, civil society organisations, stakeholders etc.), the type (conference, bilateral, tripartite etc.), and timing of the outreach efforts and whether stakeholders have been consulted selectively on specific components or whether a general consultation has taken place on a comprehensive draft plan. Member States should... explain the envisaged steps to involve and consult the relevant stakeholders in the implementation of the plans overall. (European Commission, 2021c, p. 47)

Importantly, details on required stakeholder involvement also influence the degree of centralisation. This could provide a counterweight to higher degrees of enforcement through conditionality and a final decisionrole of the European Council. After all, it seems logical that stakeholder involvement in the design and implementation phases will alter, or even improve on, any previously agreed reform plans (see Bekker, 2021). This flexibility and adaptability could be a feature of the Semester that provides relevant lessons on how to judge promised vs. actual reforms in the light of conditionality and evaluation.

\subsection{Degree of Enforcement}

Regarding delegation to third actors, Art. 19 of the Regulation gives the Commission the task of assessing the NRRPs (or updated plans) and making a proposal for a Council implementing decision. This assessment is done in close cooperation with the member state concerned. If the Commission requires additional information, the member state should provide it. The Commission may also use country information, gathered within the scope of the Semester. If needed, the Commission could ask a member state to revise its NRRP, as has actually happened (e.g., Jakubowska et al., 2021). The Commission and the member state may agree to extend the deadline for assessment by a reasonable period. The plan is checked against criteria concerning the relevance, effectiveness, efficiency, and coherence of the plans. On a proposal from the Commission, the Council shall approve the assessment of the NRRP, via an implementing decision (Art. 20), viewing the preamble by reversed qualified majority voting. Within this legal set-up, the Council thus gets the final say on approving the NRRPs but also on stalling grants if there are deviations in reaching milestones and targets (Corti \& Nunez Ferrer, 2021; De la Porte \& Dagnis Jensen, 2021). This option also sidelines the role of the EP (Closa Montero et al., 2021; Crum, 2020). If the Commission's assessment of the NRRP is positive, the proposal for an implementing decision sets out the national reforms and investment projects which the country needs to implement, including milestones, targets, and financial contributions. If the request concerns a loan, the Commission proposal for a Council implementing decision shall also set out the size of the loan and the additional reforms and investment projects to be implemented by the member state, including additional milestones and targets. Moreover, the Commission shall be empowered to adopt, by the end of December 2021, delegated acts (for an indeterminate period, although this may be revoked at any time by the European Parliament or by the Council; Art. 29-4). This empowerment has several purposes referring to the monitoring process, such as the creation of common indicators for reporting progress, and for the monitoring and evaluation of the RRF. Another purpose of having a delegated act is to define a methodology for reporting social expenditure. In order to measure progress, the Commission aims to create a resilience scoreboard (Art. 19). There is thus quite some delegation to the Commission and the Council, especially in terms of assessing whether the NRRP meets the requirements for receiving financial support, and on monitoring progress, with the Council having a final say. In terms of the loans and the governance and management structure, the RRF diverts from the structural funds whose management is shared by the national and regional authorities (Corti \& Nunez Ferrer, 2021).

Other elements of enforcement include conditional financial support and the frequency of reporting. As described above, the conditions for grants and loans are tied to EU level priorities, the division in the allocation of funds, and meeting CSRs. The financial assistance is divided into loans and grants (non-repayable financial 
support), given in two tranches: $70 \%$ of the maximum amount per country until 31 December 2022, and 30\% until 31 December 2023. Interestingly, apart from conditional financial support, the RRF is also tied to the expectation that countries meet the rules on maximum debts and deficits. Here, going from the preventive to the corrective arm of the SGP or MIP may have consequences for the financial support given via the RRF. Art. 10 of the Regulation deals with a Commission proposal of a (partial) suspension of the commitments or payments if the Council decides that a member state has not taken effective action to correct its excessive deficit (via the SGP), or excessive imbalances (via the MIP). Priority shall be given to the suspension of commitments, whereas payments shall be suspended only when immediate action is sought and in the case of significant non-compliance. Moreover, the scope and level of the suspension of commitments or payment to be imposed shall be proportionate, respect the equality of treatment between member states and take into account the economic and social circumstances of the member state concerned, in particular its level of unemployment, poverty or social condition, compared to the EU average, as well as the impact of the suspension on the national economy. In sum, enforcement will be harsher if countries move into the corrective arms of the SGP or the MIP and do not take appropriate action according to the Commission and the Council. However, the impact of withdrawing commitments (and in second instance payments) should also be considered.

Furthermore, the preamble of the Regulation addresses that there should be a match between the type of support (loan or grant) and the purpose of the financial assistance. There should also be a match with the costs of controls, the administrative burden, and the expected risk of non-compliance. Accordingly, the non-repayable financial support should take the form of a sui generis Union contribution and should be paid based on the achievement of results by reference to milestones and targets of the NRRPs. A decision to disburse the financial contribution may be made, however. Regarding the frequency of reporting and monitoring, Article 27 states that the member state shall report twice a year in the context of the Semester on the progress made, for which also the national reform programmes will be used.

\subsection{Degree of Centralisation}

Counterbalancing the enforcement aspects of the RRF are the parts of the Regulation that explicitly give priority to the national level. The preamble mentions that the NRRPs should not affect the right to conclude or enforce collective agreements or to take collective action. Moreover, the preamble states that the Commission should act in close cooperation with member states and fully respect national ownership of the plan, meaning that it should take into account justifica- tions and elements stemming from the national level. Moreover, member states may make a reasoned request to amend their plan within the period of implementation, for instance, if objective circumstances justify this. Countries may, moreover, ask the Commission to set up exchanges with other member states in order to share experiences within the drafting stage of their plans (Art. 18-5). Furthermore, the preamble mentions regional and local authorities as potentially important partners in the implementation phase. Therefore, these partners should be appropriately consulted and involved, in accordance with the national legal framework. In addition, member states should be encouraged to seek the opinion of their national productivity boards and independent fiscal institutions. Expenses to hold expert meetings and to consult stakeholders may be covered if these relate to the preparation, design, or implementation of the NRRP (Art. 6). The national parliaments are not mentioned in the Regulation. Also, the first legislative proposals on the RRF contained a marginal role for both the European and the national parliaments, although a (binding) obligation on member states to let their national parliaments approve NRRPs before submitting them to the Commission has been recommended (Crum, 2020; Guttenberg \& Nguyen, 2020).

So far, practices concerning stakeholder involvement seem mixed. The European Trade Union Confederation has a real-time monitoring tool on its website, to track down national-level trade union involvement in the drafting and implementation of the NRRPs. It shows that 13 member states do not have such involvement (including those member states who, until that point, had not yet handed in an NRRP; status May 2021). Moreover, the European Trade Union Confederation (2021b) is not satisfied with the quality of involvement in the countries where trade unions were involved. It underlines that whereas the attachment of the RRF to the Semester suggests the involvement of the social partners, neither the RRF Regulation nor the Guidelines issued by the European Commission explain how this should take place. Therefore, the European Trade Union Confederation provides such guidance itself to all policy and decision-makers.

\section{Conclusion}

This article deals with the next stage in the evolution of the Semester: its interlinkage with the RFF. Apart from linking the Semester to a new EU instrument, it adds conditional financial support. Financial support is given if NRRPs meet the predefined topics of the Regulation establishing the RRF, including reform suggestions communicated via the CSRs. This article analyses the degree of obligation, enforcement, and centralisation of the Regulation establishing the RRF. Thereby, it assesses the room the Regulation leaves for national actors, such as the national parliaments, to influence the design and implementation of reforms. Using conditional financial 
support is relatively new in the EU. It was used especially during the past financial crisis in bail-out programmes of some member states. This was criticised quite heavily, in terms of it harming democratic standards and social rights. The RRF, set up to recover from the Covid-19 pandemic, seems to differ, advocating an investment instead of an austerity approach. The conditionality in the RRF also diverts from the usual conditionally of loans used by international organisations. For instance, the RRF acknowledges that the economic problems are not caused by national economic policies, but rather by a pandemic, and moreover, does not focus solely on loans, but also gives grants.

Still, the Regulation, has quite a high degree of obligation, not in the least because the requirements for getting a grant or loan are quite precise. Also, the monitoring of results is precise, involving the checking of milestones and targets. The CSRs play a role in setting reform expectations, but a larger set of priorities is relevant as well. This high degree of obligation is counterbalanced somewhat, because national governments may articulate their reform ideas in NRRPs. It gives the national level the opportunity to formulate precise reforms and explain how this fits the national situation best. For national parliaments and social partners, it is of key relevance that they can influence the NRRPs already at this writing stage. On enforcement, the Commission and the Council get quite some influence, including the ability to set the criteria upon which a country's progress is measured. Commitments and payment may be revoked, although the Regulation speaks of exceptional cases. Particularly those countries that perpetually fail to implement reforms under the SGP or MIP could face harsher enforcement. However, future research should assess if this quite strict formulation on paper will be converted into practice. On national actor involvement, including the national parliaments, it is important to bear in mind the priority that the Regulation gives to the national level, which possibly lowers the degree of centralisation. The NRRPs should articulate how the views of a range of national stakeholders are taken into account. While the national parliaments are not mentioned in the Regulation itself, the Commission's staff working document mentions that NRRPs may include the role of national or regional parliaments as well as of the social partners. The Regulation also states that alternative reforms may be advocated, as well as amendments to plans even at the implementation stage. All these aspects taken together, national parliaments and other stakeholders should be quite proactive when wanting to exercise influence in the reform plans that are part of the RRF. They should understand that they can be involved at the NRRPs' writing stage. Moreover, when debating reform proposals in parliament, they should know that alternative reforms may be reasoned for and that NRRPs may be adjusted. Additionally, as the link of the Semester to the RRF increases the relevance of the CSRs, national stakeholders could also improve their say in designing the CSRs, and thus influence the European Commission's views of reform priorities.

\section{Acknowledgments}

I would like to thank the anonymous reviewers, and the participants of the ERC Leviathan workshop 2020, organized by Hertie School, for their constructive feedback on earlier versions of the manuscript.

\section{Conflict of Interests}

The author declares no conflict of interests.

\section{References}

Abbott, K. W., Keohane, R. O., Moravcsik, A., Slaughter, A.-M., \& Snidal, D. (2000). The concept of legalization. International Organization, 54(3), 401-419. https:// doi.org/10.1162/002081800551271

Alcidi, C., \& Gros, D. (2017). How to further strengthen the European Semester? In-depth study for the European Parliament (CEPS.PE 602.114). CEPS. https:// www.ceps.eu/ceps-publications/how-strengtheneuropean-semester

Antonucci, L., \& Corti, F. (2020). Inequalities in the European Semester. FEPS. https://www.feps-europe.eu/ attachments/publications/inequalities_in_the_ european_semester\%20online.pdf

Bekker, S. (2017). The European semester process: Adaptability and latitude in support of the European social model. In F. Vandenbroucke, C. Barnard, \& G. De Baere (Eds.), A European social union after the crisis (pp. 238-250). Cambridge University Press.

Bekker, S. (2021). Hardening and softening of countryspecific recommendations in the European Semester. West European Politics, 44(1), 114-133.

Bekker, S., \& Klosse, S. (2013). EU governance of economic and social policies: Chances and challenges for Social Europe. European Journal of Social Law, 2013(2), 103-120.

Cardwell, P. J., \& Gaglia, M. P. (2020). Research handbook on the politics of EU law. Routledge.

Chang, M., Sacher, M., \& Tkalec, I. (2019). Recent changes in EU economic governance: Methodological and institutional dynamics. Journal of Contemporary European Research, 15(2), 134-142.

Closa Montero, C., González de León, F., \& Hernández González, G. (2021). Pragmatism and the limits to the European Parliament's strategies for self-empowerment. Politics and Governance, 9(3), 163-174.

Copeland, P., \& Daly, M. (2015). Social Europe: From "add-on" to "dependence-upon" economic integration. In A. Crespy \& G. Menz (Eds.), Social policy and the Euro crisis: Quo vadis Social Europe (pp. 140-160). Palgrave Macmillan.

Corti, F., \& Nunez Ferrer, J. (2021). Steering and mon- 
itoring the Recovery and Resilience Plans (Discussion Paper No. 2). CEPS. https://www.ceps.eu/cepspublications/steering-and-monitoring

Costamagna, F., \& Goldmann, M. (2020, May 30). Constitutional innovation, democratic stagnation? The EU recovery plan. Verfassungsblog. https:// verfassungsblog.de/constitutional-innovationdemocratic-stagnation/DOI:10.17176/20200530133220-0

Council of Europe. (2012). Resolution 1884: Austerity measures: A danger for democracy and social rights. http://assembly.coe.int/ASP/Doc/XrefViewPDF.asp? FilelD $=18916 \&$ Language $=E N$

Crum, B. (2018). Parliamentary accountability in multilevel governance: What role for parliaments in postcrisis EU economic governance? Journal of European Public Policy, 25(2), 268-286.

Crum, B. (2020). How to provide political guidance to the Recovery and Resilience Facility? European Parliament.

De la Porte, C., \& Dagnis Jensen, M. (2021). The next generation EU: An analysis of the dimensions of conflict behind the deal. Social Policy and Administration. https://doi.org/10.1111/spol.12709

De la Porte, C., \& Heins, E. (2015). A new era of European integration? Governance of labour market and social policy since the sovereign debt crisis. Comparative European Politics, 13(1), Article 8.

Dutch Government. (2021). Stability programme, April 2021. https://ec.europa.eu/info/sites/default/files/ 2021-netherlands-stability-programme_en.pdf

EU. (2021). Regulation (EU) 2021/241 of the European Parliament and of the Council of 12 February 2021 establishing the Recovery and Resilience Facility. http://data.europa.eu/eli/reg/2021/241/oj

Eurofound. (2016). Role of the social partners in the European Semester.

European Commission. (2021a). European Semester 2021-an exceptional cycle, main website of the European Commission on the Semester, available at https://ec.europa.eu/info/business-economyeuro/economic-and-fiscal-policy-coordination/eueconomic-governance-monitoring-preventioncorrection/european-semester/european-semestertimeline/european-semester-2021-exceptionalcycle_en

European Commission. (2021b, May 17). Recovery and Resilience Facility: Cyprus submits official recovery and resilience plan [Press release]. https://ec.europa. eu/commission/presscorner/detail/en/ip_21_2527

European Commission. (2021c), Commission staff working document; Guidance to member states Recovery and Resilience Plans, (SWD(2021) 12 final, Part 1/2).

European Trade Union Confederation. (2021a, May 11). RRF: Spanish unions and European Trade Union Confederation write to the European Commission to stop interference in social dialogue [Press release]. https://est.etuc.org/?p=829
European Trade Union Confederation. (2021b). Trade union inputs for national recovery and resilience plans.

Fink, F., \& Scholl, A. (2016). A quantitative model of sovereign debt, bailouts and conditionality. Journal of International Economics, 98, 176-190.

Fleming, S., Johnson, M., \& Dombey, D. (2021, February 10). Draghi and the EU's recovery mission. Financial Times. https://www.ft.com/content/7c2007d9$6 c e 9-4895-a c 5 c-c d 17 e 3 b f 69 b 2$

Guttenberg, L., \& Nguyen, T. (2020, June 11). How to spend it right: A more democratic governance for the EU Recovery and Resilience Facility. Bertelsmann Stiftung, Jacques Delors Centre. https:// www.bertelsmann-stiftung.de/fileadmin/files/BSt/ Publikationen/GrauePublikationen/20200610 How_to_spend_it_right_Guttenberg_Nguyen.pdf

Hooghe, L., \& Marks, G. (2019). Grand theories of European integration in the twenty-first century. Journal of European Public Policy, 26(8), 1113-1133.

Jacoby, W., \& Hopkin, J. (2020). From lever to club? Conditionality in the European Union during the financial crisis. Journal of European Public Policy, 27(8), 1157-1177.

Jakubowska, J., Plevák, O., Szicherle, P., \& Gabrizova, Z. (2021, February 10). Drafting national recovery plans: A laborious exercise for Visegrad countries. Euractiv. https://www.euractiv.com/section/economy-jobs/ news/drafting-national-recovery-plans-a-laboriousexercise-for-visegrad-countries

Kilpatrick, C., \& de Witte, B. (2014). Social rights in times of crisis in the Eurozone: The role of fundamental rights' challenges. European University Institute.

Kość, W., \& Tamma, P. (2021, March 15). Polish political crisis over EU pandemic recovery fund. Politico. https://www.politico.eu/article/polandgovernment-coalition-crisis-united-right-eucoronavirus-recovery-fund

Munta, M. (2021). EU socio-economic governance in Central and Eastern Europe. Routledge.

Papadopoulos, Y., \& Piattoni, S. (2018, June 15). The European Semester: Democratic weaknesses as limits to learning. SGEU.

Rijksoverheid. (2020, May 26). Non-paper EU support for efficient and sustainable Covid-19 recovery. https://www.rijksoverheid.nl/documenten/ publicaties/2020/05/26/non-paper-eu-support-forefficient-and-sustainable-covid-19-recovery

Sabato, S., Vanhercke, B., \& Spasova, S. (2017). Listened to, but not heard? Social partners' multilevel involvement in the European Semester (Paper Series No. 35). European Social Observatory.

Saurugger, S., \& Terpan, F. (2021). Normative transformations in the European Union: On hardening and softening law. West European Politics, 44(1), 1-20.

Scharpf, F. W. (2002). Notes toward a theory of multilevel governing in Europe. Scandinavian Political Studies, 24(1), 1-26. 
Schmidt, V. A. (2018). Rethinking EU Governance: From "old" to "new" approaches to who steers integration. JCMS: Journal of Common Market Studies, 56(7), 1544-1561.

Schmidt, V. A. (2020). Theorizing institutional change and governance in European responses to the Covid-19 pandemic. Journal of European Integration, 42(8), 1177-1193.

Theodoropoulou, S. (2015). National social and labour market policy reforms in the shadow of EU bailout conditionality: The cases of Greece and Portugal. Comparative European Politics, 13, 29-55.

Vanheuverzwijn, P., \& Crespy, A. (2018). Macroeconomic coordination and elusive ownership in the European Union. Public Administration, 96(3), 578-593.

Verdun, A., \& Zeitlin, J. (2018). Introduction: The European Semester as a new architecture of EU socioeconomic governance in theory and practice. Journal of European Public Policy, 25(2), 137-148.
Viță, V. (2018). Research for REGI committee: Conditionalities in cohesion policy. European Parliament. https://www.europarl.europa.eu/RegData/etudes/ STUD/2018/617498/IPOL_STU(2018)617498_EN. pdf

Wieser, T. (2020). What role for the European Semester in the recovery plan? European Parliament. https:// www.bruegel.org/wp-content/uploads/2020/10/ IPOL_IDA2020651368_EN.pdf

Woźniakowski, T. P., Maatsch, A., \& Miklin, E. (2021). Rising to a challenge? Ten years of parliamentary accountability of the European Semester. Politics and Governance, 9(3), 96-99.

Zeitlin, J. (2016). EU experimentalist governance in times of crisis. West European Politics, 39(5), 1073-1094.

Zeitlin, J., \& Vanhercke, B. (2018). Socializing the European Semester: EU social and economic policy co-ordination in crisis and beyond. Journal of European Public Policy, 25(2), 149-174.

\section{About the Author}

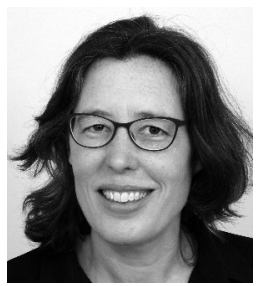

Sonja Bekker is an Associate Professor of European Social Policy at Utrecht University and Tilburg University, both in the Netherlands. She is Programme Director of the ERI research cluster on Empirical Legal Research into Institutions for Conflict Resolution. She publishes on the European Semester and workers who have vulnerable labour market positions, for instance as part of the Horizon 2020 project WorkYP on in-work poverty. Between 2017 and 2020 she held a Jean Monnet Chair in European Social Policy and Employment Relations. 